\title{
Fabrication of Surface-Hybrid-MMCs Layer on Aluminum Plate by Friction Stir Processing and Its Wear Characteristics
}

\author{
Essam R. I. Mahmoud*, Makoto Takahashi, Toshiya Shibayanagi and Kenji Ikeuchi \\ Joining and Welding Research Institute, Osaka University, Ibaraki 567-0047, Japan
}

Aluminum-base hybrid composites reinforced with mixtures of $\mathrm{SiC}$ and $\mathrm{Al}_{2} \mathrm{O}_{3}$ particles $1.25 \mu \mathrm{m}$ in average size have been fabricated on an A 1050-H24 aluminum plate by friction stir processing (FSP) and their wear resistance has been investigated as a function of the relative weight ratios of the particles. A mixture of $\mathrm{SiC}$ and $\mathrm{Al}_{2} \mathrm{O}_{3}$ powders of different weight ratios was packed into a groove of $3 \mathrm{~mm}$ width and $1.5 \mathrm{~mm}$ depth cut on the aluminum plate, and covered with an aluminum sheet $2 \mathrm{~mm}$ thick. A FSP tool of square probe shape, rotated at a speed of $1500 \mathrm{rpm}$, was plunged into the plate through the cover sheet and the groove, and moved along the groove at a travelling speed of $1.66 \mathrm{~mm} / \mathrm{s}$. After the hybrid composite was fabricated on the Al plate, the homogeneity of the particles distribution inside the Al matrix has been evaluated from the macro/microstructure and hardness distribution. Moreover, the wear characteristics of the resulted hybrid composites were evaluated using a ball-on-disc wear tester at room temperatures at normal loads of 2 and $5 \mathrm{~N}$. As a result, it was found that the reinforcement particles were distributed homogenously inside the nugget zone without any defects except some voids that appeared around the $\mathrm{Al}_{2} \mathrm{O}_{3}$ particles. The average hardness decreased with increasing the relative content of $\mathrm{Al}_{2} \mathrm{O}_{3}$ particles. Regarding the wear characteristics, the wear volume losses of the hybrid composites depended on the applied load and the relative ratio of $\mathrm{SiC}$ and $\mathrm{Al}_{2} \mathrm{O}_{3}$ particles. The hybrid composite of $80 \% \mathrm{SiC}+20 \% \mathrm{Al}_{2} \mathrm{O}_{3}$ showed superior wear resistance to $100 \% \mathrm{SiC}$ and $\mathrm{Al}_{2} \mathrm{O}_{3}$ or any other hybrid ratios at a normal load of $5 \mathrm{~N}$. [doi:10.2320/matertrans.M2009092]

(Received March 16, 2009; Accepted April 9, 2009; Published June 3, 2009)

Keywords: friction stir processing, aluminum, $\mathrm{SiC}, \mathrm{Al}_{2} \mathrm{O}_{3}$, surface composites, wear resistance

\section{Introduction}

Surface metal matrix composites (SMMCs) exhibit a unified combination of high tribological properties of the surface and high toughness of the interior bulk metal when compared with both metal matrix composites (MMCs) and monolithic materials. ${ }^{1-5)}$ Selecting reinforcement remains one of the most critical factors in realizing the best properties from the resultant SMMCs. ${ }^{6-9)}$ The widely used particles for reinforcing $\mathrm{Al}$ alloys are silicon carbide $(\mathrm{SiC})$ and alumina $\left(\mathrm{Al}_{2} \mathrm{O}_{3}\right) .{ }^{10-15)}$ Besides their high hardness, they show low density and low cost comparing with other reinforcements. In the past two decades, the wear resistance of the aluminum alloys reinforced with $\mathrm{SiC}$ and $\mathrm{Al}_{2} \mathrm{O}_{3}$ in many forms (particles, whiskers and fibers) and sizes has been described by a huge body of publications. ${ }^{6-20)}$ Most studies $^{6-16)}$ proved that $\mathrm{SiC}$ was more effective than $\mathrm{Al}_{2} \mathrm{O}_{3}$ in the improvement of wear resistance of the resultant aluminum composite due to its higher hardness. ${ }^{6-16)}$ On the other hand, some investigations ${ }^{17-20)}$ suggested that $\mathrm{Al} / \mathrm{Al}_{2} \mathrm{O}_{3}$ composites were more stable and inert, and had better corrosion and high temperature behavior than $\mathrm{Al} / \mathrm{SiC}^{.17-20)}$ In this sense, it may become practical to use both $\mathrm{SiC}$ particles and $\mathrm{Al}_{2} \mathrm{O}_{3}$ particles (hybrid) as reinforcements to gain both of their benefits for improving the composite properties.

Hybrid MMCs are engineering materials reinforced by a combination of two or more different type and/or form of substances in order to achieve the combined advantages of both of them. This gives a rather high degree of freedom in material design. ${ }^{16)}$ It was reported in many works ${ }^{10-12,21-25)}$ that the hybrid composites of $\mathrm{SiC}$ and $\mathrm{Al}_{2} \mathrm{O}_{3}$ exhibited better wear resistance than those reinforced only with the $\mathrm{SiC}$ or $\mathrm{Al}_{2} \mathrm{O}_{3}$. ${ }^{10-12,21-25)}$

*Graduate Student, Osaka University
It is generally known that the fabrication of SMMCs by traditional fusion surfacing techniques such as laser beam and thermal spraying may lead to the deterioration of MMCs properties. ${ }^{26-30)}$ In the case of $\mathrm{Al}_{2} \mathrm{O}_{3}$, the $\mathrm{Al}_{2} \mathrm{O}_{3}$ may decompose to $\mathrm{Al}$ and oxygen gas (forming porosities) on contact with liquid aluminum in addition to the tendency of the $\mathrm{Al}_{2} \mathrm{O}_{3}$ particle to clustering. ${ }^{30)}$ Similarly, the $\mathrm{SiC}$ may react with molten aluminum to form brittle $\mathrm{Al}_{4} \mathrm{C}_{3}$ carbide. ${ }^{21,29)}$ Moreover, one of the severe problems in preparation of hybrid composites by normal fusion process is the agglomeration of each reinforcement, which results in inhomogeneous reinforcement distribution in the matrix. ${ }^{31)}$ Considering these problems, friction stir processing (FSP) seems to be a good candidate for successful fabrication of hybrid SMMCs on the Al plate. ${ }^{29)}$

Friction stir processing (FSP) is a microstructure modification technique developed by Mishra ${ }^{32)}$ based on the concept of friction stir welding, but its goal is different. ${ }^{29,32,33)} \mathrm{A}$ non-consumable rotating tool consisting of a shoulder and a probe is plunged into a single piece of material, and provides frictional heating and mechanical mixing in the area covered by the tool. ${ }^{29,32,33)}$ It is considered that SMMCs are one of the latest applications of FSP. ${ }^{34-40)}$ The stirring action and frictional heat generated by the FSP tool can be used to distribute ceramic particles as reinforcement on the surface of light metals like aluminum and magnesium. ${ }^{34-40)}$

The present authors ${ }^{39,40)}$ succeeded in uniformly distributing $\mathrm{SiC}$ particles of $1.25 \mu \mathrm{m}$ size in a surface layer of a few $\mathrm{mm}$ thickness on $\mathrm{Al} 1050-\mathrm{H} 24$ plates to form surface composites by FSP.

In the present work, aiming to obtain the hybrid composites by FSP of excellent tribological properties, we plan to extend our study of surfacing the 1050-H24 Al to include the possibility to distribute two types of reinforcements: $\mathrm{SiC}$ and $\mathrm{Al}_{2} \mathrm{O}_{3}$ particles. 

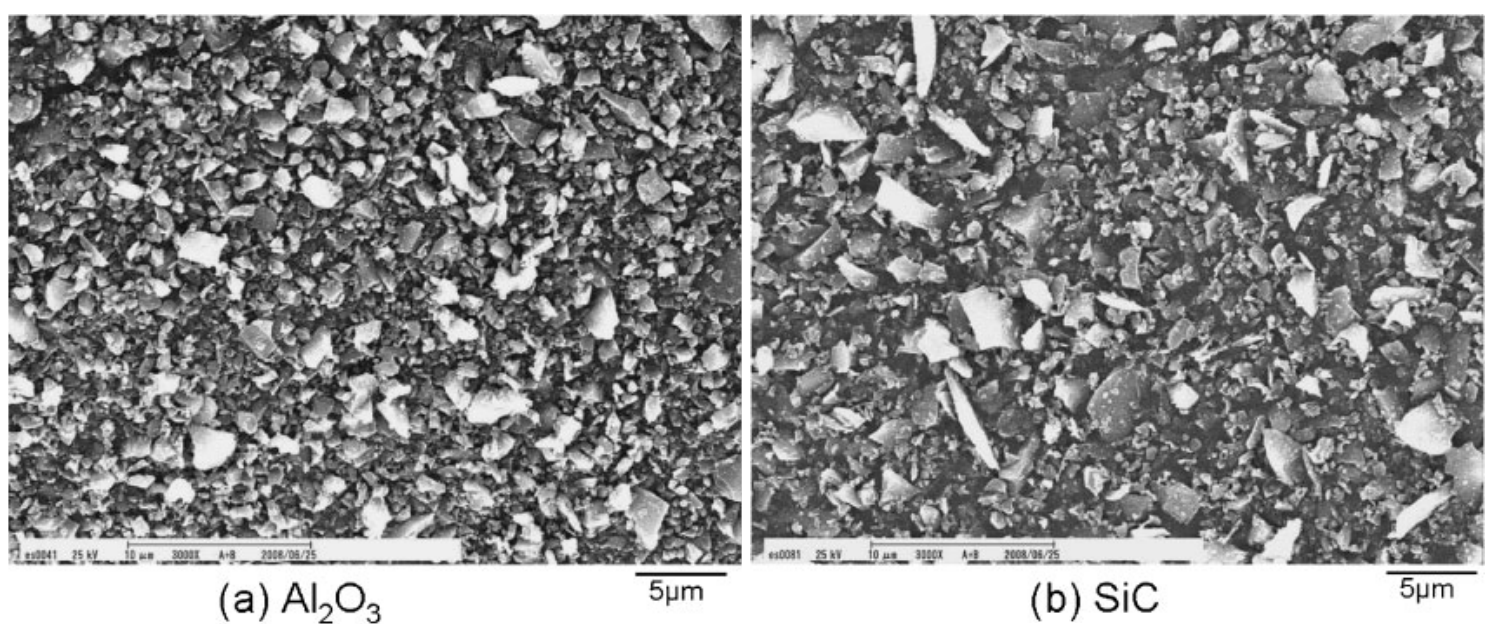

Fig. 1 SEM images of the as-received $\mathrm{Al}_{2} \mathrm{O}_{3}$ and $\mathrm{SiC}$ powders.

\section{Experimental Setup}

Commercially pure aluminum Al-1050-H24 plates of $5 \mathrm{~mm}$ thickness were used as the base material. Mixtures of $\mathrm{SiC}$ and $\mathrm{Al}_{2} \mathrm{O}_{3}$ particles at different ratios were used as the reinforcements. They had similar average particle diameters of $1.25 \mu \mathrm{m}$ as shown in Fig. 1.

A tool of steel SKD61 with a shoulder of $14 \mathrm{~mm}$ diameter and a square probe of $5 \mathrm{~mm}$ diagonal length and $3.3 \mathrm{~mm}$ height was used to perform the FSP. The reinforcement powder was packed in a groove of $3 \mathrm{~mm}$ width and $1.5 \mathrm{~mm}$ depth cut on the Al plate. An aluminum sheet of $2 \mathrm{~mm}$ thickness was used to cover the groove filled with the reinforcement powders to prevent them from going out before they were incorporated into the aluminum matrix during the FSP. The tool was rotated at a rotation speed of $1500 \mathrm{rpm}$, and travelled at a speed of $1.66 \mathrm{~mm} / \mathrm{s}$ with a tilt angle of $3^{\circ}$. These conditions produced the best results in terms of homogeneity of the particles inside the nugget zone for producing the SMMCs of the pure $\mathrm{Al}$ reinforced with $\mathrm{SiC}$ particles. ${ }^{39,40)}$ Double and triple passes were applied in order to improve the homogeneity of the reinforcement particle distribution. In the second pass, the tool was travelled along the same line as the first and third ones but in the opposite direction. This means that the advancing side of the first and third passes became the retreating side in the second pass (refer to Refs. 39) and 40)). Macro- and microstructure observations were performed on the cross-section of the FSP specimens. Scanning electron microscope (SEM, ELIONIX, ERA-8800FE) was used to study the distribution of reinforcement particles. The microhardness was measured with AKASHI Model Vickers hardness tester at $200 \mathrm{~g}$ load applied for $15 \mathrm{~s}$ through the mid-plane of the cross-section of the nugget of each condition. The hardness distribution was measured along three parallel lines that were $1-2 \mathrm{~mm}$ deep from the upper surface and separated by a distance of $0.5 \mathrm{~mm}$. The interval between the indentations on the same line was $0.75 \mathrm{~mm}$. All measured data along the three lines were collected and averaged for each condition. The nugget zones produced by FSP triple passes were analyzed by X-ray diffractometer, (XRD, D 8 Discover with GADDS system, $35 \mathrm{kv}, 80 \mathrm{~mA}, \mathrm{MoK} \alpha$ radiation) to identify experimentally the phases that were present inside the FSP nugget zone after 3 passes.

The wear behavior of the SMMCs was evaluated by using a ball-on-disk (FPR-2100, RHESCA CO., LTD) tester in air at room temperatures. Stainless steel balls (SUS 304) with a diameter of $4.5 \mathrm{~mm}$ were used as the counterpart material. Before the test, all the specimens were ground on emery paper up to 600 grade until the end of the cover sheet, which was consider almost the FSP nugget zone center. The tests were carried out at normal loads of 2 and $5 \mathrm{~N}$ applied to the SUS 304 balls. The radius of the ball travelling was $6 \mathrm{~mm}$, the rotation speed was $100 \mathrm{rpm}$ (linear velocity of $31.4 \mathrm{~mm} / \mathrm{s}$ ) and the total rotation time was $1 \mathrm{ks}$. The friction force was recorded automatically against time by the tester software. The friction coefficient of the stainless steel ball against the SMMCs was calculated from the ratio of the friction force to the normal load. The wear volume loss was measured with a surface profilometer (SURFOM 1400D) at 8 different locations (every $45^{\circ}$ ) along the wear track, and the average of the measured values represented the mean wear volume losses of the specimen. Examples of the surface profilometer charts of the cross-section area of the wear tracks are shown in Fig. 2. The wear track was examined with a scanning electron microscope (SEM, ELIONIX, ERA-8800FE) at low magnifications to discuss the wear mechanism. For comparison, the wear behaviors of the nugget zone of a pure aluminum produced by FSP without reinforcements under the same processing conditions were also investigated.

\section{Experimental Results and Discussion}

\subsection{Composites homogeneity after first pass}

Macroscopic appearances of the nugget zone in which $\mathrm{SiC}$, $\mathrm{SiC}+\mathrm{Al}_{2} \mathrm{O}_{3}$ and $\mathrm{Al}_{2} \mathrm{O}_{3}$ powders were dispersed by the first FSP pass are shown in Fig. 3. In general, the macroscopic particle distribution inside the area under the shoulder that subjected to intense plastic deformation during FSP or so called "nugget zone" ${ }^{29)}$ was almost similar regardless the reinforcement type. This is due to that all the samples were fabricated at the same rotation speed of $1500 \mathrm{rpm}$ and with a tool of the same design, which were the main parameters that control the material flow inside the nugget zone as mentioned 


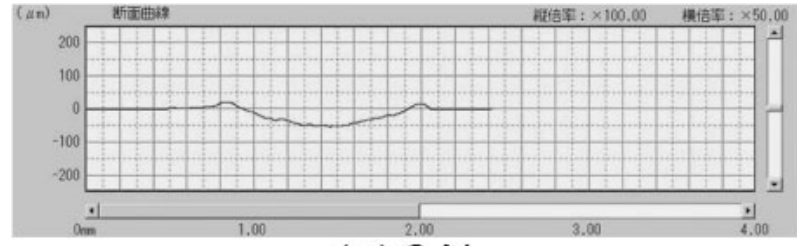

(a) $2 \mathrm{~N}$

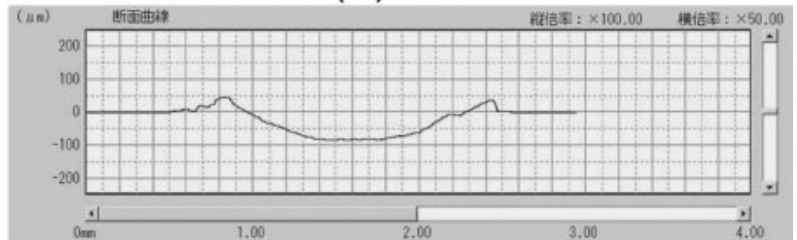

(b) $5 \mathrm{~N}$

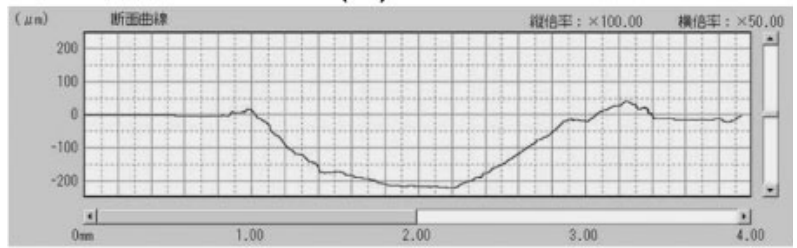

(c) $10 \mathrm{~N}$

Fig. 2 Examples of surface profilometer charts of wear tracks produced at different loads.

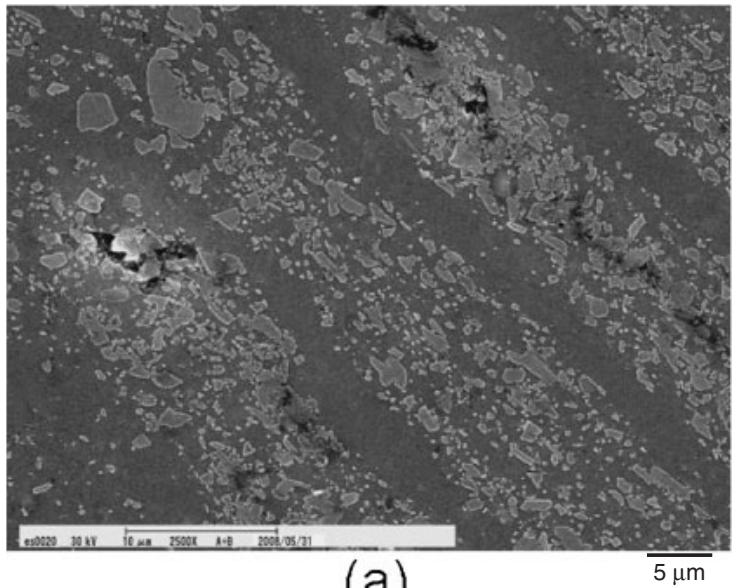

(a)

Fig. 4 SEM images of some local areas in Fig. 3 after the first pass: (a) banded structure in Fig. 3(a) and (b) reinforcement particles clusters in Fig. 3(b).

in our previous works. ${ }^{39,40)}$ The reinforcement particles were distributed in a banded structure towards the top of the advancing side, leaving the retreating side and the central top portions with low density of reinforcement particles. The banded structure was clearer when the reinforcement was $\mathrm{SiC}$ particles as shown in Fig. 4(a). Some reinforcement particles clustering were observed inside the nugget zone as indicate by arrows in Fig. 3 and as shown in Fig. 4(b). These clustering areas were increased with the content of $\mathrm{Al}_{2} \mathrm{O}_{3}$ particles (compare Fig. 3(a) with Fig. 3(c)).

\subsection{Composites properties after triple passes}

Macroscopic appearances of the nuggets cross-sections produced by triple FSP passes with different relative contents of $\mathrm{SiC}$ and $\mathrm{Al}_{2} \mathrm{O}_{3}$ powders are shown in Fig. 5. As expected, the reinforcement particles were distributed more widely and

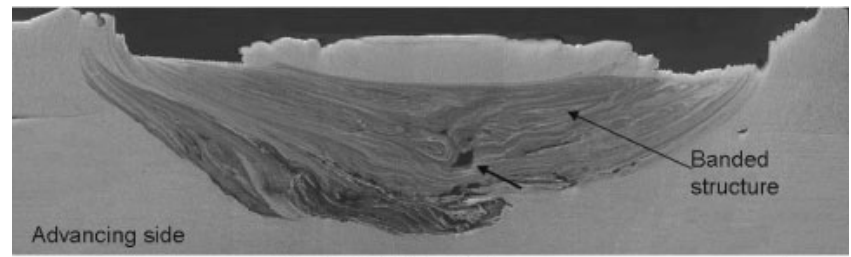

(a) $100 \% \mathrm{SiC}$

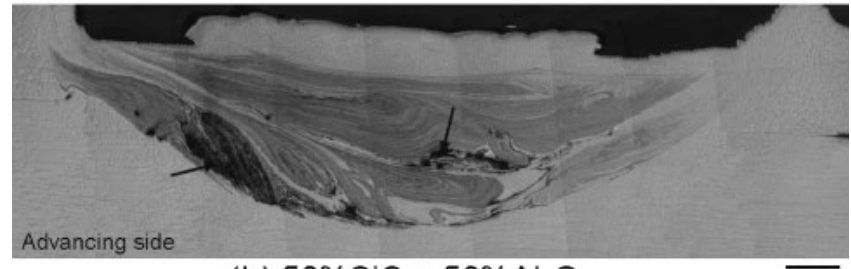

(b) $50 \% \mathrm{SiC}+50 \% \mathrm{Al}_{2} \mathrm{O}_{3}$

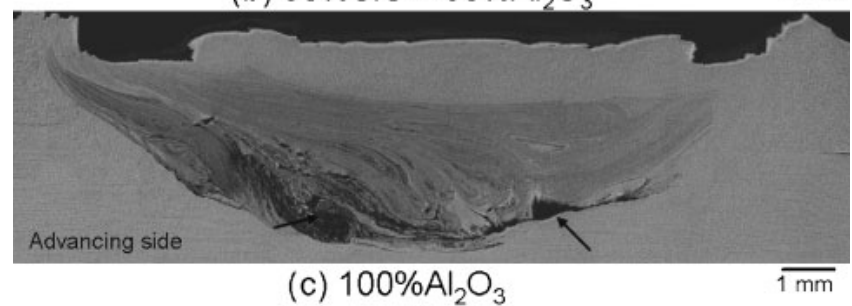

Fig. 3 Micrographs of the nugget zone cross-section after the first FSP pass.

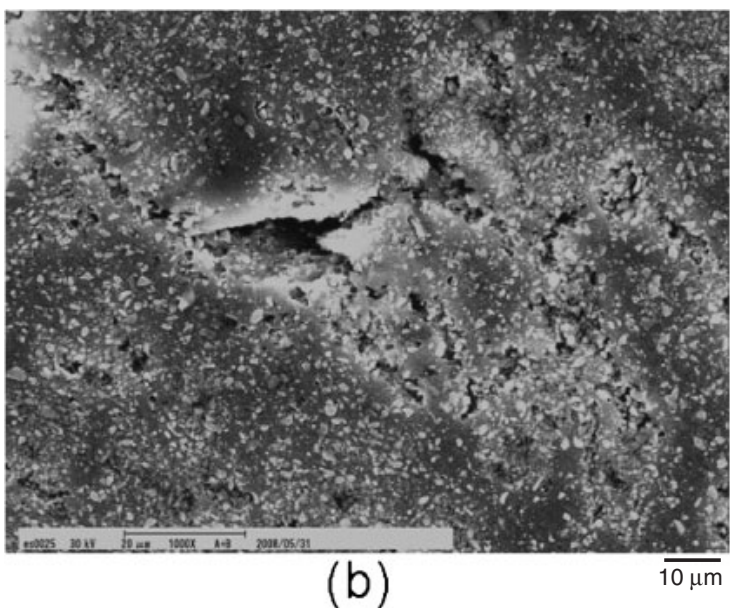

(b) uniformly in the nugget zone for all weight ratios of $\mathrm{SiC}$ and $\mathrm{Al}_{2} \mathrm{O}_{3}$ powders by applying three FSP passes. This was due to the stirring action generated in every pass by the rotated tool. In the same time the reinforcement density on the advancing side became almost similar to that on the retreating side. This was due to the opposite travelling direction of the second pass to the first and third passes. The macroscopic behavior of the powder mixtures of $\mathrm{SiC}$ and $\mathrm{Al}_{2} \mathrm{O}_{3}$ inside the nugget zone was quite similar regardless their relative content except for small variations in the nugget zone homogeneity; i.e., small reinforcement clustering was detected at the lower part of the nugget zone when the ratio of $\mathrm{Al}_{2} \mathrm{O}_{3}$ was not less than $80 \%$ (see Figs. 5(h) and (i)). On the other hand, some small elongated onion ring structures were appeared inside the nugget zone when the $\mathrm{SiC}$ ratio was high (see Figs. 5(a), (b), and (c)). 


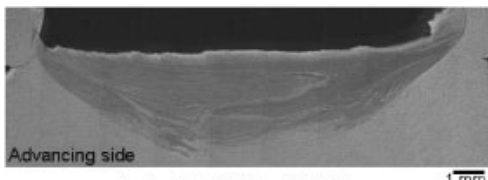

(a) $100 \% \mathrm{SiC}$

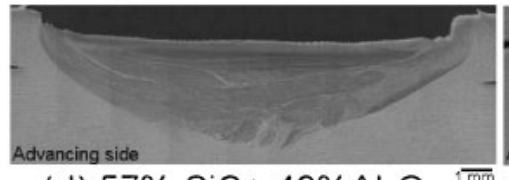

(d) $57 \% \mathrm{SiC}+43 \% \mathrm{Al}_{2} \mathrm{O}_{3}$

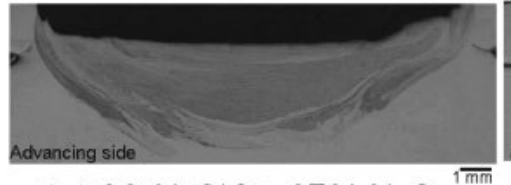

(g) $33 \% \mathrm{SiC}+67 \% \mathrm{Al}_{2} \mathrm{O}_{3}$

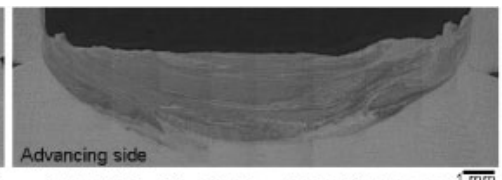

(b) $80 \% \mathrm{SiC}+20 \% \mathrm{Al}_{2} \mathrm{O}_{3}$

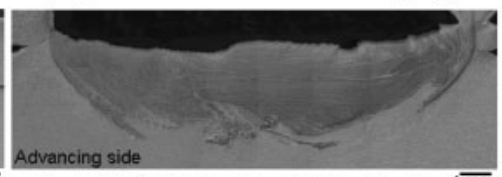

(e) $50 \% \mathrm{SiC}+50 \% \mathrm{Al}_{2} \mathrm{O}_{3}$

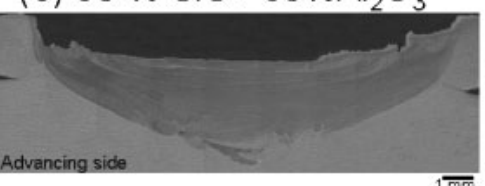

(h) $20 \% \mathrm{SiC}+80 \% \mathrm{Al}_{2} \mathrm{O}_{3}$

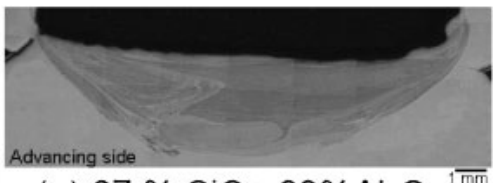

(c) $67 \% \mathrm{SiC}+33 \% \mathrm{Al}_{2} \mathrm{O}_{3}$

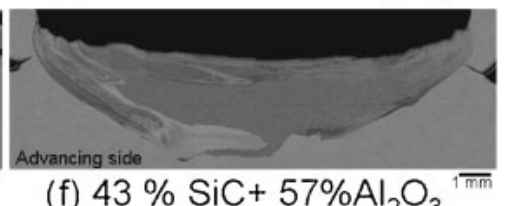

(f) $43 \% \mathrm{SiC}+57 \% \mathrm{Al}_{2} \mathrm{O}_{3}{ }^{1}$

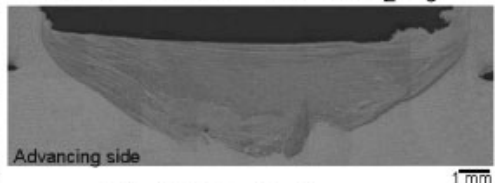

(i) $100 \% \mathrm{Al}_{2} \mathrm{O}_{3}$

Fig. 5 Micrographs of the nugget zone cross-section of different hybrid composites.

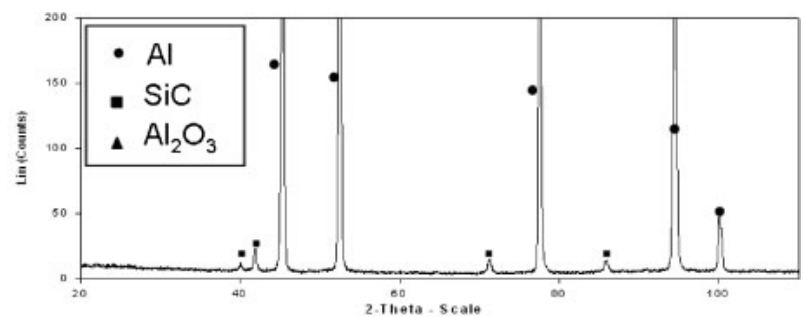

(a) $100 \% \mathrm{SiC}$

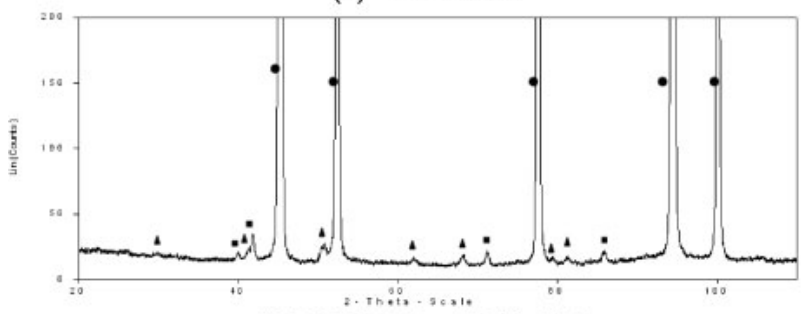

(b) $50 \% \mathrm{SiC}+50 \% \mathrm{Al}_{2} \mathrm{O}_{3}$

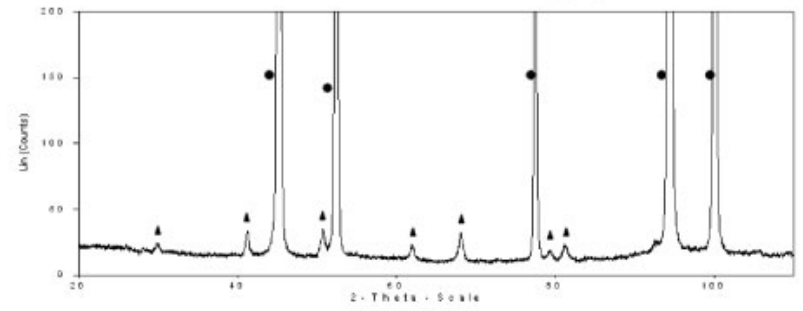

(c) $100 \% \mathrm{Al}_{2} \mathrm{O}_{3}$

Fig. 6 XRD patterns of nugget zone cross-section after triple passes.

On the other hand, as stated in our previous paper, ${ }^{40)}$ the multi-pass FSP has almost no effect on the size of the nugget zone. This is due to that the following FSP pass was done after the sample was cooled down to room temperatures. ${ }^{40)}$ Moreover, the FSP tool was eroded by the hard ceramic particles $\left(\mathrm{SiC}\right.$ and $\mathrm{Al}_{2} \mathrm{O}_{3}$ ) and the worn material (mainly iron) reacted with $\mathrm{Al}$ matrix to form iron aluminides as described in details in our previous work. ${ }^{40)}$

The XRD patterns of the nugget zone cross-sections that had different reinforcement ratios are shown in Fig. 6. It was clear that there were no new phases except the added reinforcement powders $\left(\mathrm{SiC}, \mathrm{Al}_{2} \mathrm{O}_{3}\right)$ and the aluminum matrix. This suggests that no reaction occurred between the $\mathrm{SiC}$ and $\mathrm{Al}_{2} \mathrm{O}_{3}$ powders or between the aluminum matrix and the powders during three FSP passes, which can be considered to be a merit of the FSP as a surfacing technique over other traditional fusion surfacing techniques such as laser beam and thermal spraying. ${ }^{29)}$ It was reported by many authors ${ }^{14,21,30)}$ that there were undesirable interfacial reactions between the matrix and the reinforcement during fabrication by liquid surfacing techniques. For example, Majumdar et al., ${ }^{14)}$ detected large Al-carbide plates at the $\mathrm{SiC} / \mathrm{Al}$ of $\mathrm{SiC}$ particles introduced onto Al-substrate by laser injection. This reaction product $\mathrm{Al}_{4} \mathrm{C}_{3}$ is very brittle, which degrades the composite material especially in humid environments. ${ }^{14)}$

Microscopically, the SEM images of the centers of the nugget cross-section, as shown in Fig. 7, suggest that the particle distribution in the matrix was almost uniform under all the processed conditions. These areas represents the most important area in the nugget zone practically, this is due to that surfacing is done by applying many adjacent parallel passes to cover the area of interest. The adjacent pass will overlap the advancing or retreating side of the previous one which share in more particle distribution. The central portion of the nugget tends to remain as it is without changes. However, presence of small voids around some particles or at the particle/matrix interface was observed in the nugget zones of higher $\mathrm{Al}_{2} \mathrm{O}_{3}$ contents. By EDS analyses, it was found that these micro voids were mainly located around the $\mathrm{Al}_{2} \mathrm{O}_{3}$ particles while it was less noticeable around $\mathrm{SiC}$ particles as shown in Fig. 8. This may be related to the better wettability of the $\mathrm{SiC}$ with aluminum matrix than that of $\mathrm{Al}_{2} \mathrm{O}_{3}{ }^{6,12)}$

The EDS mapping of $\mathrm{Si}$ and $\mathrm{O}$ in the center of the nugget zone of different powder ratios were carried out to observe the $\mathrm{SiC}$ and $\mathrm{Al}_{2} \mathrm{O}_{3}$ particles distribution. The reliability of oxygen by EDS is relatively weak, but we use it only to detect the $\mathrm{Al}_{2} \mathrm{O}_{3}$ particles not to measure its amounts. As shown in Fig. 9, it is clear from the mapping that both $\mathrm{SiC}$ and $\mathrm{Al}_{2} \mathrm{O}_{3}$ particles were mixed together in the nugget zone; i.e., they 


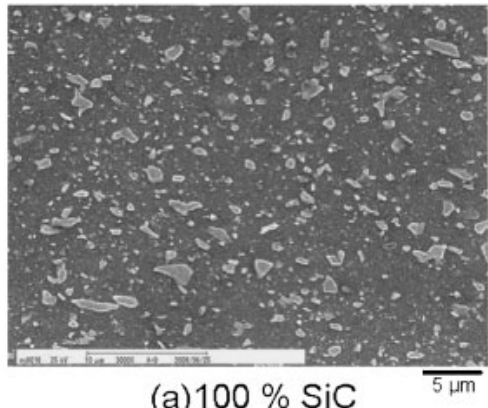

(a) $100 \% \mathrm{SiC}$

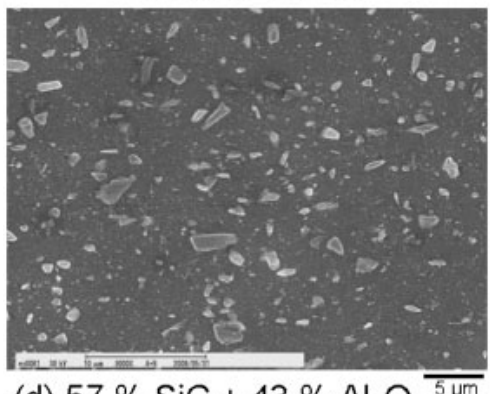

(d) $57 \% \mathrm{SiC}+43 \% \mathrm{Al}_{2} \mathrm{O}_{3}{ }^{5 \mu m}$

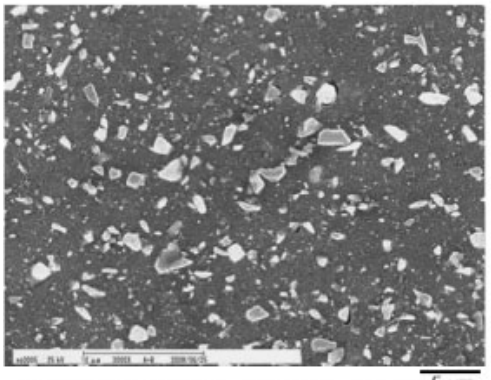

(g) $33 \% \mathrm{SiC}+67 \% \mathrm{Al}_{2} \mathrm{O}_{3}^{5 \text { pmm }}$

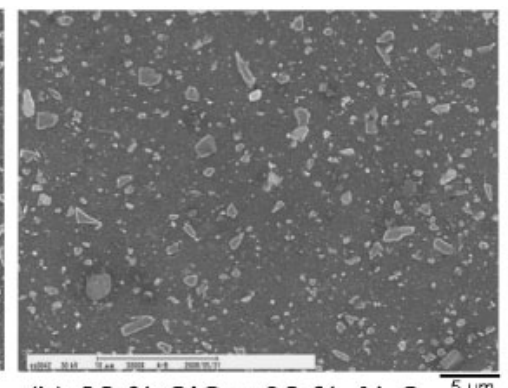

(b) $80 \% \mathrm{SiC}+20 \% \mathrm{Al}_{2} \mathrm{O}_{3}$

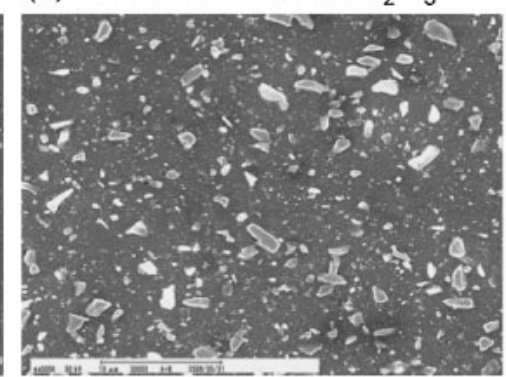

(e) $50 \% \mathrm{SiC}+50 \% \mathrm{Al}_{2} \mathrm{O}_{3}{ }^{5 \mu m}$

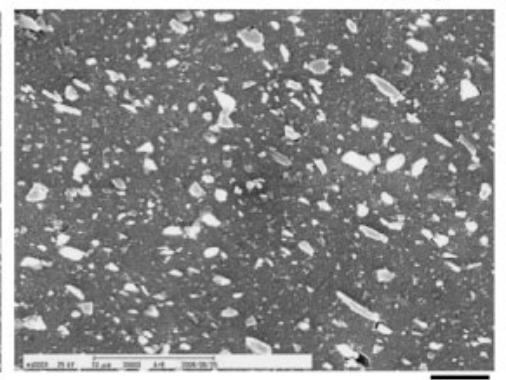

(h) $20 \% \mathrm{SiC}+80 \% \mathrm{Al}_{2} \mathrm{O}_{3}^{\overline{5}}$

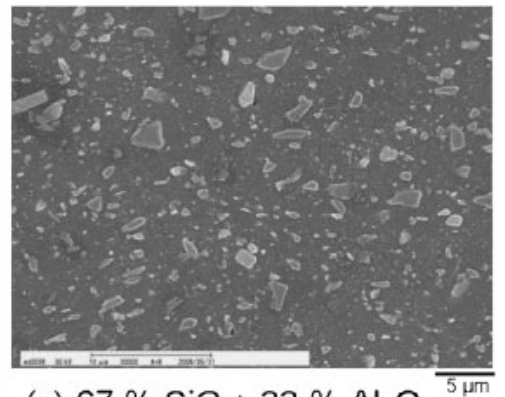

(c) $67 \% \mathrm{SiC}+33 \% \mathrm{Al}_{2} \mathrm{O}_{3}{ }^{5}$

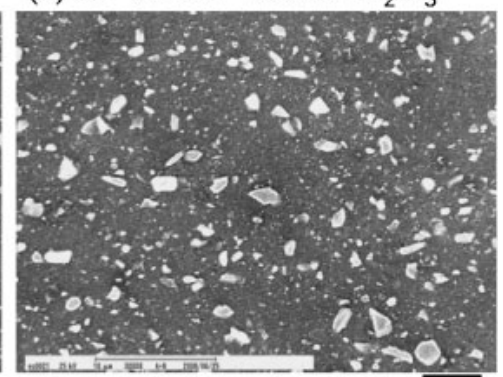

(f) $43 \% \mathrm{SiC}+57 \% \mathrm{Al}_{2} \mathrm{O}_{3}{ }^{5}$

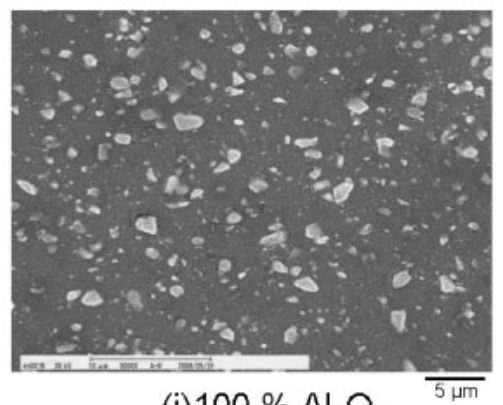

(i) $100 \% \mathrm{Al}_{2} \mathrm{O}_{3}$

Fig. 7 SEM micrographs of the nugget center with different hybrid composites.

exhibited no separate clustering or banding of one type of reinforcement compared with the other, or in other words, they behaved as one type of reinforcement. This may be due to the strong stirring action which was considered to be one of the most prominent advantages of FSP over all welding and surfacing processes. ${ }^{29,33-40)}$ It was reported by some literatures ${ }^{22,31)}$ that one of the problems in the fabrication of the hybrid-MMCs by fusion processes or even by other ordinary solid-state processes such as power metallurgy (PM) was the agglomeration of the deferent reinforcements, especially the finer particles. ${ }^{22)}$

In contrast to the reinforcement particles distribution over the most areas of the nugget zone, there were some inhomogeneity in the peripheral areas as shown in Fig. 10. The reinforcement particles tended to be dispersed in banded structure as shown in Fig. 10(a). In the retreating and advancing sides, reinforcement particles of relatively high density or clustering were detected as shown in Figs. 10(b) and $10(\mathrm{c})$. In the lower part of the nugget zone, when the ratio of $\mathrm{Al}_{2} \mathrm{O}_{3}$ was higher than $80 \%$, some dense reinforcement areas were observed as shown in Fig. 10(d). These inhomogeneous distributions appeared only in the peripheral areas of the nugget zone where the effect of the tool stirring action became weak.

The average microhardness of the nugget zone is plotted against the relative content ratio of $\mathrm{Al}_{2} \mathrm{O}_{3}$ in the reinforce- ment in Fig. 11. As compared with average hardness $\sim 23 \mathrm{HV}$ of the FSP nugget zone without reinforcement, the hardness values of the reinforced composites were increased by twice ( $\sim 47 \mathrm{HV})$ for $100 \% \mathrm{Al}_{2} \mathrm{O}_{3}$ and almost three times $(\sim 60 \mathrm{HV})$ for $100 \% \mathrm{SiC}$. It was revealed from the diagram that the hardness tended to decrease almost linearly with an increase in the relative amount of $\mathrm{Al}_{2} \mathrm{O}_{3}$ content in the composite. This is partially because of the higher hardness of the $\mathrm{SiC}$ particles than $\mathrm{Al}_{2} \mathrm{O}_{3}$ particles. The existence of micro voids at the $\mathrm{Al}_{2} \mathrm{O}_{3}$ particle/matrix interface also seems to share in lowering the hardness of the composite material. According to the previous works, the obtained hardness values are quite similar to other MMCs fabricated by FSP and also other methods if we take into consideration that our substrate was pure Al. For example, Morisada et al. ${ }^{35)}$ distributed $\mathrm{SiC}$ particles in AZ31 $(\mathrm{HV} \approx 40)$ with FSP, and the hardness of the resulted MMCs was about $70 \mathrm{HV}$. Ünlü ${ }^{20)}$ fabricated Al/ Al2O3 MMCs with powder metallurgy and the resulted hardness was $55 \mathrm{HV}$. Reihani ${ }^{10)}$ fabricated Al6061/SiC with squeeze casting and the hardness was about $85 \mathrm{HV}$. On the other hand Anandkumar ${ }^{11)}$ surfaced the Al-Si $(90 \mathrm{HV})$ alloy with $\mathrm{SiC}$ particles by laser cladding and the hardness reached $120 \mathrm{HV}$.

\subsection{Wear characteristics}

In order to investigate the effect of $\mathrm{Al}_{2} \mathrm{O}_{3} / \mathrm{SiC}$ ratio on the 


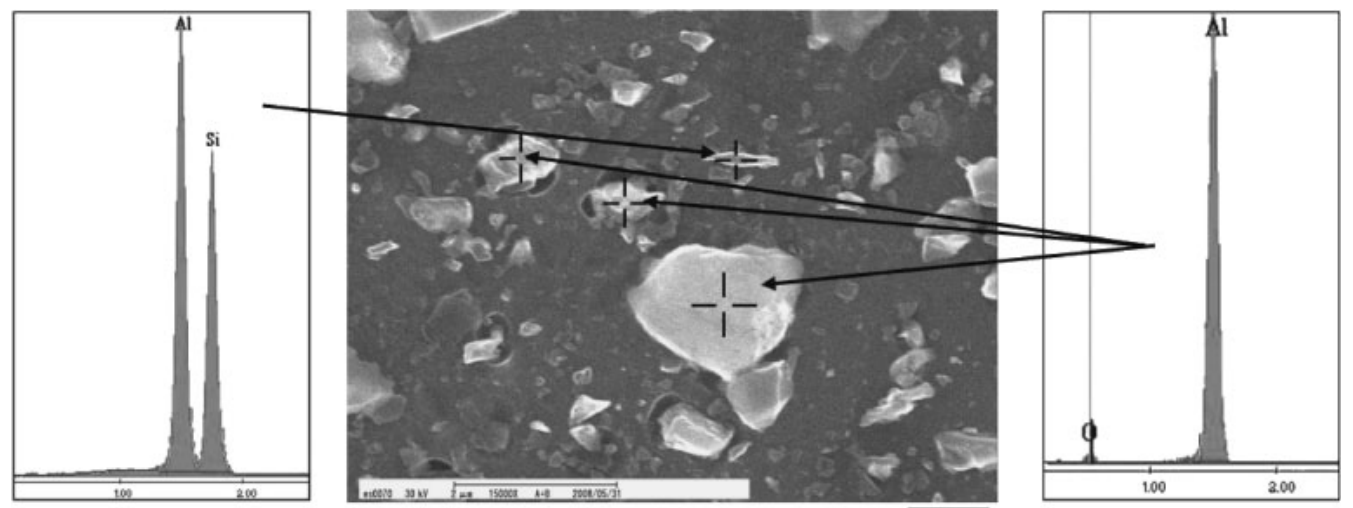

(a) $20 \% \mathrm{SiC}+80 \% \mathrm{Al}_{2} \mathrm{O}_{3}$

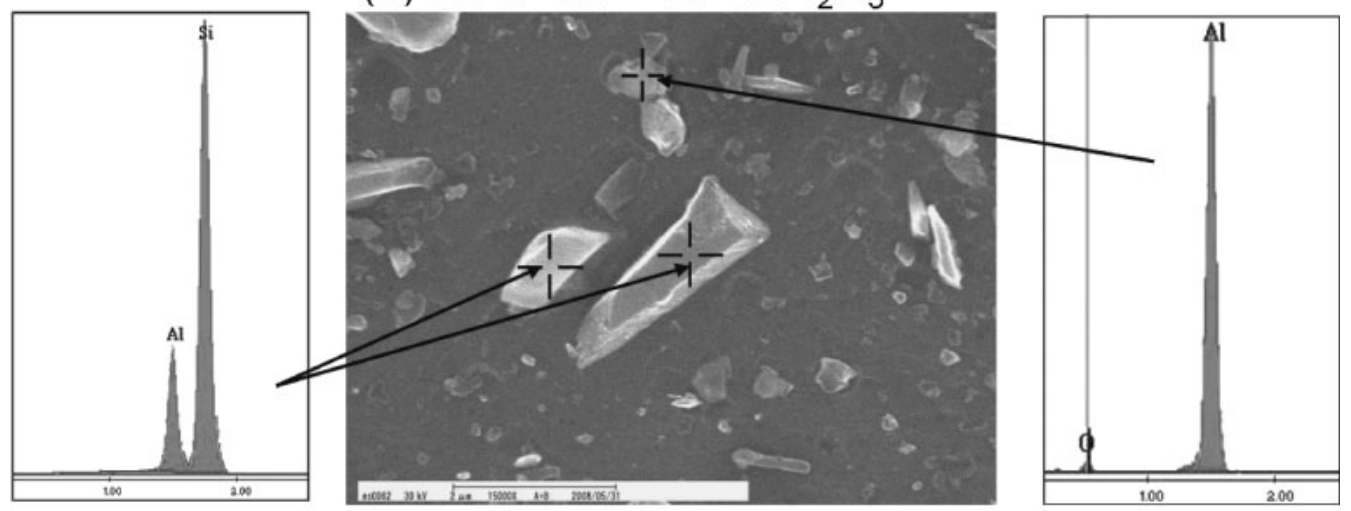

(b) $67 \% \mathrm{SiC}+33 \% \mathrm{Al}_{2} \mathrm{O}_{3}$

Fig. 8 SEM images of particles of $\mathrm{SiC}$ and $\mathrm{Al}_{2} \mathrm{O}_{3}$ incorporated in the nugget zone and EDS spectra for some of them: (a) $80 \% \mathrm{Al}_{2} \mathrm{O}_{3}$ and (b) $33 \% \mathrm{Al}_{2} \mathrm{O}_{3}$.
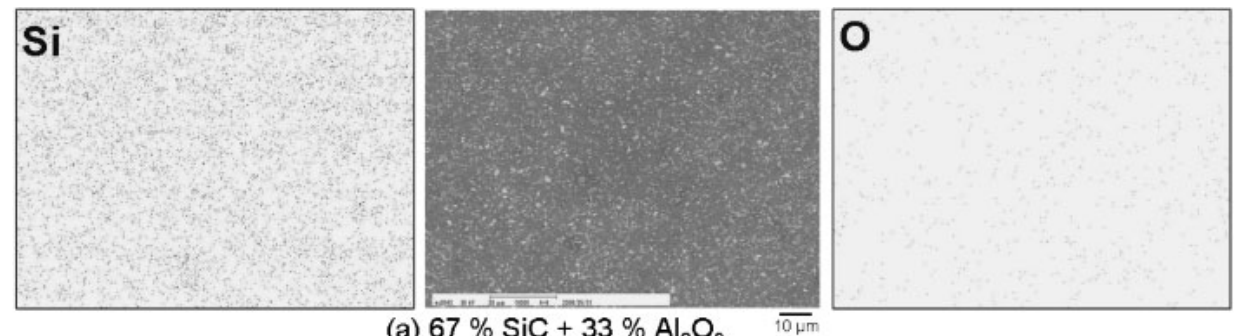

(a) $67 \% \mathrm{SiC}+33 \% \mathrm{Al}_{2} \mathrm{O}_{3}$
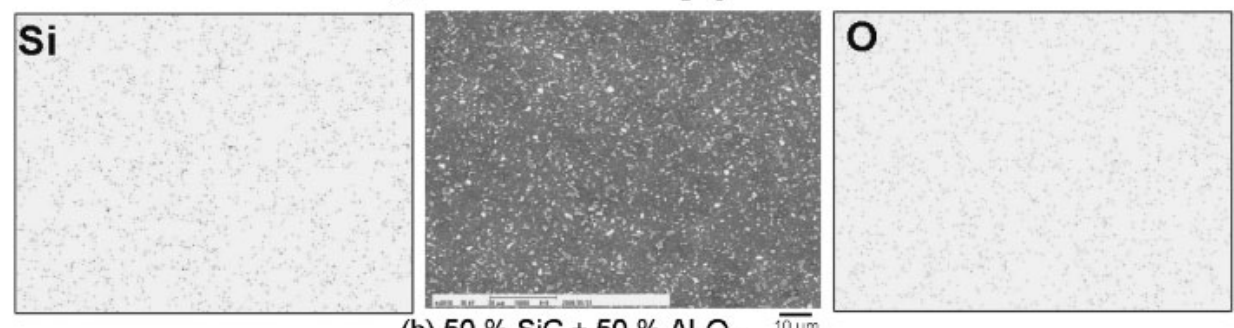

(b) $50 \% \mathrm{SiC}+50 \% \mathrm{Al}_{2} \mathrm{O}_{3}$
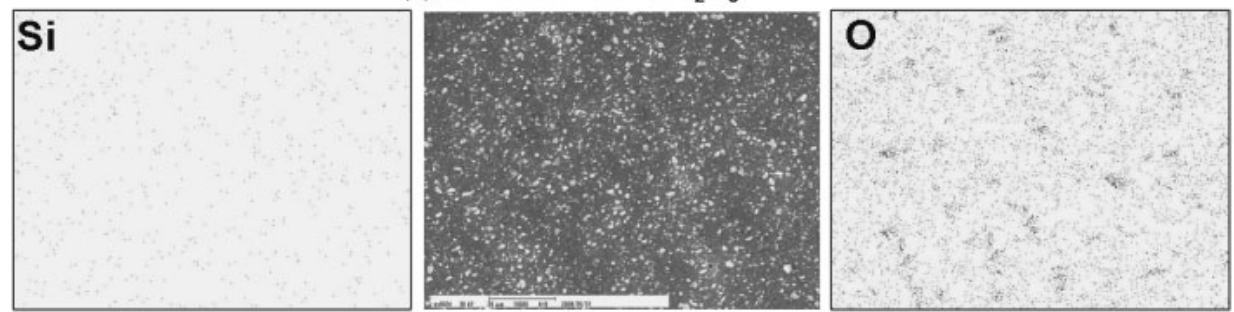

(c) $20 \% \mathrm{SiC}+80 \% \mathrm{Al}_{2} \mathrm{O}_{3} \overline{10 \mathrm{~mm}}$

Fig. 9 EDS image mapping of $\mathrm{Si}$ (for $\mathrm{SiC}$ ) and $\mathrm{O}$ (for $\mathrm{Al}_{2} \mathrm{O}_{3}$ ) at the center of nugget zone containing hybrid composite of: (a) $67 \%$ $\mathrm{SiC}+33 \% \mathrm{Al}_{2} \mathrm{O}_{3}$, (b) $50 \% \mathrm{SiC}+50 \% \mathrm{Al}_{2} \mathrm{O}_{3}$, and (c) $20 \% \mathrm{SiC}+80 \% \mathrm{Al}_{2} \mathrm{O}_{3}$. (the central figures are SEM images of the nugget zone center while the right and left ones are their EDS mapping) 


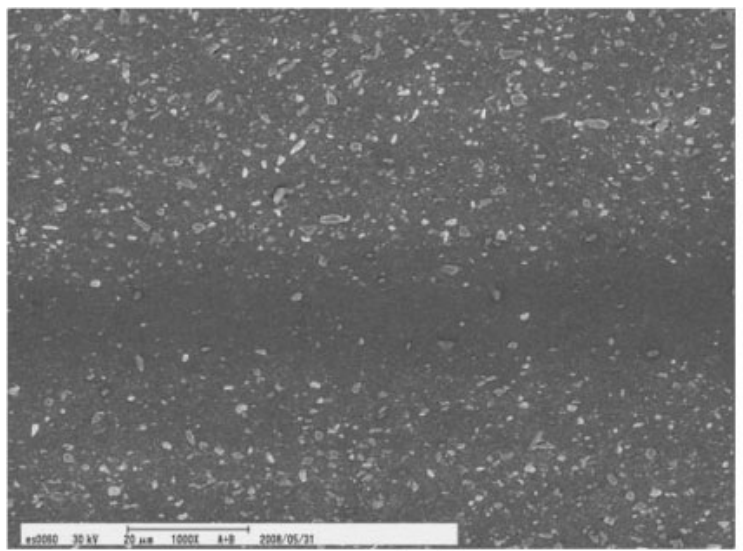

(a)

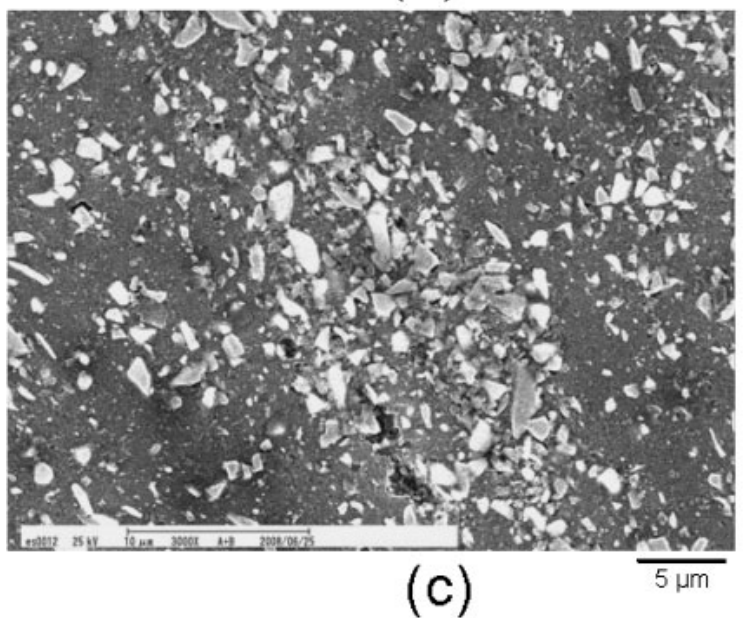

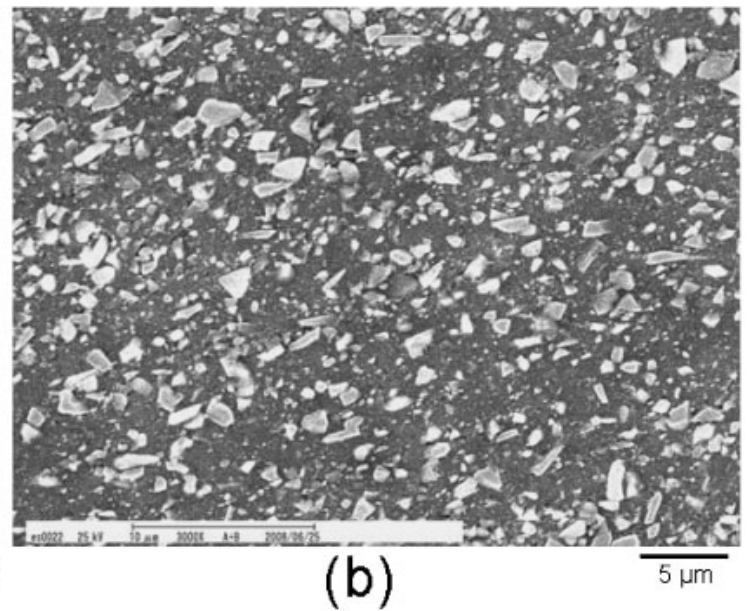

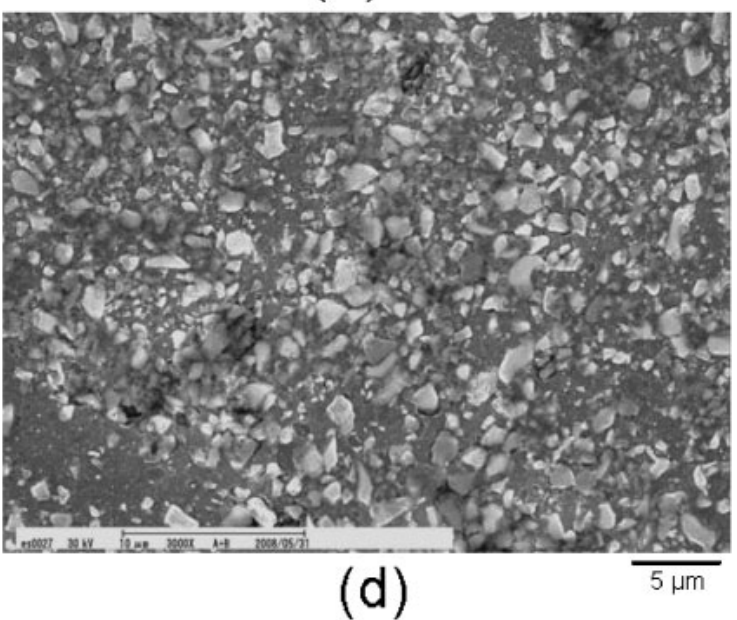

Fig. 10 SEM images of some local areas inside the nugget zones: (a) Banded structure in sample a, (b) high reinforcement density in retreating side of sample e, (c) Elongated clustering in advancing side of sample g, and (d) $\mathrm{Al}_{2} \mathrm{O}_{3}$ particles clusters in bottom side of sample i.

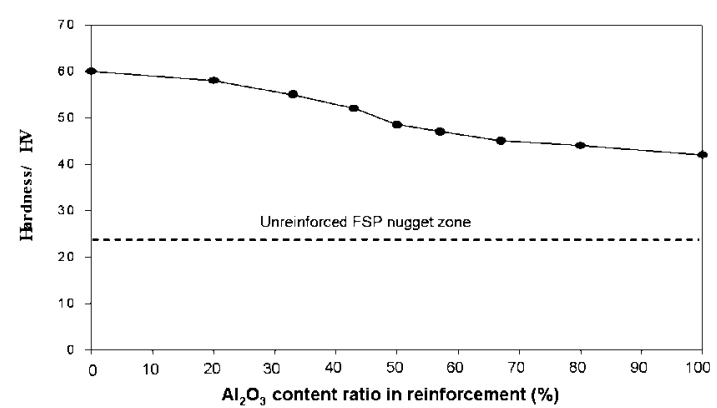

Fig. 11 Effect of the $\mathrm{Al}_{2} \mathrm{O}_{3}$ content ratio in the reinforcement on the average hardness of the resulted FSP nugget zone measured at mid-crosssection.

wear resistance of the FSP nugget zones, the average friction coefficients and wear volume losses were plotted against the $\mathrm{Al}_{2} \mathrm{O}_{3}$ relative ratio in reinforcements in Figs. 12 and 13, respectively. As shown in Fig. 12, the average friction coefficient values exhibited general tendency to decrease with increasing the relative content of $\mathrm{Al}_{2} \mathrm{O}_{3}$ at normal loads of 2 and $5 \mathrm{~N}$. It was reported that the $\mathrm{Al}_{2} \mathrm{O}_{3}$ powder had a lower friction coefficient $0.4^{41}$ ) than that of $\mathrm{SiC} 0.7^{42)}$ when they were tested under the same conditions. Therefore, it may be expected that the composites that contained higher ratios of $\mathrm{Al}_{2} \mathrm{O}_{3}$ particles will have lower friction coefficients.

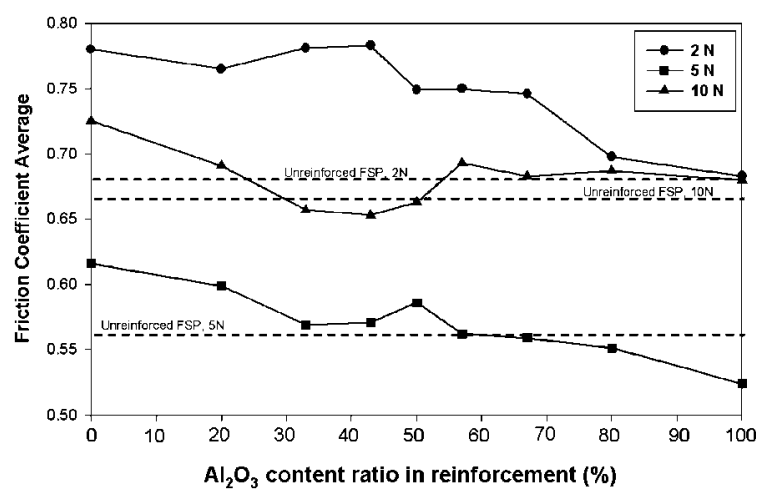

Fig. 12 Effect of hybrid ratio of reinforcements on the average friction coefficient at normal applied loads of 2, 5, $10 \mathrm{~N}$.

Furthermore, it is clear that the average friction coefficient decreased with increasing the normal applied load from 2 to $5 \mathrm{~N}$ at all composite ratios. The decrease in the average friction coefficient with normal applied load was in agreement with many works. ${ }^{43-46)}$

Figure 13 shows that the addition of reinforcement powder ( $\mathrm{SiC}, \mathrm{Al}_{2} \mathrm{O}_{3}$ or mixture) to an aluminum matrix was beneficial in reducing the wear volume losses at normal loads of 2 and $5 \mathrm{~N}$. The wear volume values, at normal loads of $2 \mathrm{~N}$, increased with the $\mathrm{Al}_{2} \mathrm{O}_{3}$ particles relative ratio in the 


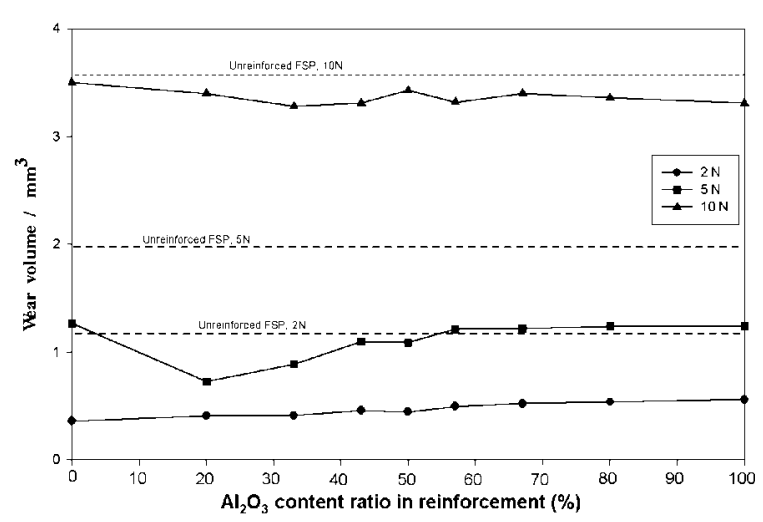

Fig. 13 Effect of hybrid ratio of reinforcements on wear volume losses at normal applied loads of $2,5,10 \mathrm{~N}$.

hybrid composites. On the other hand, the hybrid composites containing $\mathrm{Al}_{2} \mathrm{O}_{3}$ particles relative ratio of $20 \%$ were superior in wear resistance to other composites at a normal load of $5 \mathrm{~N}$ suggesting that the hybrid composites exhibited better wear resistance than those reinforced with only one type of reinforcement.

\section{Conclusion}

In this work, we presented a detailed study on fabrication and wear properties of hybrid composites that was produced in a surface layer of pure $\mathrm{Al}$ plate by dispersing a mixture of $\mathrm{SiC}$ and $\mathrm{Al}_{2} \mathrm{O}_{3}$ particles through friction stir processing. The following conclusions can be drawn from the results obtained:

(1) The reinforcement particles $\left(\mathrm{SiC}, \mathrm{Al}_{2} \mathrm{O}_{3}\right.$ or their mixture) were distributed almost homogenously over the nugget zone by FSP without any defects except small some voids forming around the $\mathrm{Al}_{2} \mathrm{O}_{3}$ particles.

(2) The average hardness of the resulted composites increased to about $60 \mathrm{HV}$ at $100 \% \mathrm{SiC}$ (almost 3 times that of the nugget zone without reinforcement) and it decreased with increasing the relative ratio of $\mathrm{Al}_{2} \mathrm{O}_{3}$ particles.

(3) The average friction coefficient decreased with increasing the relative ratio of $\mathrm{Al}_{2} \mathrm{O}_{3}$ particles in the reinforcement.

(4) Wear characteristics of the composites were varied depending on applied load and the relative ratio of $\mathrm{SiC}$ and $\mathrm{Al}_{2} \mathrm{O}_{3}$. At a normal load of $2 \mathrm{~N}$, the wear resistance decreased with increasing the $\mathrm{Al}_{2} \mathrm{O}_{3}$ particles ratio in the reinforcement. However, at a normal load of $5 \mathrm{~N}$, the hybrid composites containing $20 \% \mathrm{Al}_{2} \mathrm{O}_{3}+$ $80 \% \mathrm{SiC}$ exhibited superior wear resistance to other relative ratios of the $\mathrm{Al}_{2} \mathrm{O}_{3}$ and $\mathrm{SiC}$ particles.

\section{REFERENCES}

1) D. B. Miracle: Compos. Sci. Technol. 65 (2005) 2526-2540.

2) S. Das: Trans. Indian Inst. Met. 57 (2004) 325-334.

3) T. Shinoda and M. Kawai: Surf. Cast. Technol. 169-170 (2003) 456459.

4) Z. H. Melgarejo, O. M. Suárez and K. Sridharan: Scr. Mater. 55 (2006)
95-98.

5) K. Funatani: Surf. Coat. Technol. 133-134 (2000) 264-272.

6) K. M. Shorowordi, T. Laoui, A. S. M. Haseeb, J. P. Celis and L. Froyen: J. Mater. Process. Technol. 142 (2003) 738-743.

7) J. Zhang, K. Sun, J. Wang, B. Tian, H. Wang and Y. Yin: Thin Solid Films 516 (2008) 5681-5685.

8) W. Żórawski, R. Chatys, N. Radek and J. B. Jamrozek: Surf. Coat. Technol. 202 (2008) 4578-4582.

9) M. R. Rosenberger, C. E. Schvezov and E. Forlerer: Wear 259 (2005) 590-601.

10) S. M. Seyed Reihani: Mater. Design 27 (2006) 216-222.

11) R. Anandkumar, A. Almeida, R. Colaço, R. Vilar, V. Ocelik and J. Th. M. De Hosson: Surf. Coat. Technol. 201 (2007) 9497-9505.

12) H. Ahlatci, T. Koçer, E. Candan and H. Çimenoğlu: Tribol. Int. 39 (2006) 213-220.

13) R. L. Deuis, C. Subramanian and J. M. Yellup: Wear 201 (1996) 132144.

14) J. D. Majumdar, B. R. Chandra and I. Manna: Wear 262 (2007) 641648.

15) C. Y. H. Him, S. C. Lim and M. Gupta: Wear 255 (2003) 629-637.

16) X. N. Zhang, L. Geng and G. S. Wang: J. Mater. Process. Technol. 176 (2006) 146-151.

17) M. Kõk: Compos. A 27 (2006) 457-464.

18) O. Yilmaz and S. Buuytoz: Compos. Sci. Technol. 61 (2001) 23812392.

19) G. de Portu, S. Guicciardi, C. Melandri and F. Monteverde: Wear 262 (2007) 1346-1352

20) B. Sadik Ünlü: Mater. Design 29 (2008) 2002-2008.

21) M. Gui and S. B. Kang: Mater. Lett. 51 (2001) 396-401.

22) S. C. Tjong, K. C. Lau and S. Q. Wu: Metall. Mater. Trans. A 30A (1999) 2551-2555.

23) M. Gui and B. Kang: Metall. Mater. Trans. A 32A (2001) 2383-2392.

24) A. B. Gurcan and T. N. Baker: Wear 188 (1995) 185-191.

25) H. Fu, K. Han and J. Song: Wear 256 (2004) 705-713.

26) L. Dubourg, F. Hiawka and A. Cornet: Surf. Coat. Technol. 151-152 (2002) 329-332.

27) M. Aparecida Pinto, N. Cheung, M. Clara Filippini Ierardi and A. Garcia: Mater. Charact. 50 (2003) 249-253.

28) Z. Znamirowski, L. Pawlowski, T. Cichy and W. Czarczynski: Surf. Coat. Technol. 187 (2004) 37-46.

29) R. S. Mishra and Z. Y. Ma: Mater. Sci. Eng. R 50 (2005) 1-78.

30) D. Storjohann, O. M. Barabash, S. S. Babu, S. A. David and P. S. Sklad: Metall. Mater. Trans. A 36A (2005) 3237-3247.

31) R. K. Uyyuru, M. K. Surappa and S. Brusethaug: Trib. Int. 40 (2007) 365-373.

32) R. S. Mishra, M. W. Mahoney, S. X. McFadden, N. A. Mara and A. K. Mukherjee: Scr. Mater. 42 (2000) 163-168.

33) Z. Y. Ma: Metall. Mater. Trans. A 39A (2008) 642-658.

34) R. S. Mishra, Z. Y. Ma and I. Charit: Mater. Sci. Eng. A 341 (2003) 307-310.

35) Y. Morisada, H. Fujii, T. Nagaoka and M. Fukusumi: Mater. Sci. Eng. A 433 (2006) 50-54.

36) L. B. Johannes, L. L. Yowell, E. Sosa, S. Arepalli and R. S. Mishra: Nanotechnology 17 (2006) 3081-3084.

37) Y. Morisada, H. Fujii, T. Nagaoka and M. Fukusumi: Mater. Sci. Eng. A 433 (2006) 50-54.

38) C. J. Lee, J. C. Huang and P. J. Hsieh: Scr. Mater. 54 (2006) 14151420 .

39) E. R. I. Mahmoud, K. Ikeuchi and M. Takahashi: Sci. Technol. Weld. Join. 13 (2008) 607-618.

40) E. R. I. Mahmoud, K. Ikeuchi, T. Shibayanagi and M. Takahashi: Sci. Technol. Weld. Join. 14 (2009) 713-725.

41) R. G. Munro: J. Am. Ceram. Soc. 80 (1997) 1919-1928.

42) R. G. Munro: J. Phys. Chem. Refer. Data 25 (1997) 1195-1203.

$43)$ R. A. Saravanan, J. Lee and S. Kang: Metall. Mater. Trans. A 30A (1999) 2523-2538.

44) J. Lee, S. Kang and J. Han: Wear 264 (2008) 75-85.

45) J. L. Mo and M. H. Zhu: Trib. Int. 41 (2008) 1161-1168.

46) A. E. Jiménez, M. D. Bermúdez, J. Cintas and E. J. Herrera: Wear 266 (2009) 255-265. 